\title{
HUMAN RESOURCE MANAGEMENT AND TECHNOLOGY DEVELOPMENT IN ARTIFICIAL INTELLIGENCE ADOPTION IN THE UAE ENERGY SECTOR
}

\author{
Hassan Ali Hassan Altaffaq ALMARASHDA ${ }^{a^{*}}$, Ishak Bin BABA ${ }^{\text {a }}$, Azizul Azhar \\ RAMLI $^{\mathrm{b}}$, Aftab Hameed MEMON ${ }^{*}$, Ismail Abdul RAHMAN ${ }^{\mathrm{d}}$ \\ $a^{a^{*}}$ Faculty of Engineering Technology, Universiti Tun Hussein Onn Malaysia (UTHM), 86400 Parit Raja, Batu \\ Pahat, Johor, Malaysia, E-mails: *hah1121@ @otmail.com, ishak@uthm.edu.my \\ ${ }^{b}$ Faculty of Computer Science \& Information Technology, Universiti Tun Hussein Onn Malaysia (UTHM), \\ 86400 Parit Raja, Batu Pahat, Johor, Malaysia, E-mail: azizulr@uthm.edu.my \\ ${ }^{c *}$ Department of Civil Engineering, Quaid-e-Awam University of Engineering, Sciences and Technology \\ Nawabshah, Pakistan,E-mail: aftabm78@ hotmail.com \\ ${ }^{\mathrm{d}}$ Faculty of Civil and Environmental Engineering, Universiti Tun Hussein Onn Malaysia (UTHM), 86400 Parit \\ Raja, Batu Pahat, Johor, Malaysia, E-mail: ismailar@uthm.edu.my
}

Received: 05.10.2021 / Accepted: 25.10.2021 / Revised: 13.11.2021 / Available online: 15.12.2021

DOI: $10.2478 /$ jaes-2021-0010

KEYWORDS: AI, energy sector, UAE, human resource management, quantitative study.

\begin{abstract}
:
Artificial Intelligence (AI) is proved a very effective technique in reducing complexity and making suitable quick decisions for achieving success. Artificial Intelligence is an emerging area and growing fast. It is used successfully in various fields. In UAE also, AI is being used in several sectors. Now the government of UAE has promoted AI in the energy sector to get the maximum of its benefits. Hence, this study evaluated various indicators that affect the promotion of AI in the energy section of the UAE. With the help of a questionnaire survey, 350 questionnaire forms were analyzed to prioritize the parameters affecting AII adoption. From the analysis results it was found that "Organization use AI to provide effective business innovation", "Organizations use AI to align with its business strategy", and "Organization use AI to improve the levels of production" are the key motivating factor to adopt AI. Significant parameters of AI technology include are; AI Technology is user friendly, AI Technology is able to improve the quality of the work and AI Technology fits well with the tasks involved; are reported as significant technological parameters to adopt AI. On the other hand, Referral person is required if facing difficulty with AI technology, and teammate support in using AI technology are essential parameters of the human resource management which affect AI adoption in the energy sector of the UAE. In addition, reliability and normality tests validated the data. Hence, these findings can be used to promote AI and understand the situation for making proper decisions.
\end{abstract}

\section{INTRODUCTION}

Artificial Intelligence (AI) is the branch of computer science in making computers behave like humans. AI technology is popularized due to robust databases and the high level of computing facilities. It has helped faster data processing and interpretation to perform routine and non-routine tasks successfully (Russell \& Norvig, 2012; Brynjolfsson \& Mitchell, 2017; Frey \& Osborne, 2017). AI techniques are now widely used with beneficial effects such as reducing food waste in the hospitality industry (Pirani \& Arafat, 2016). Recently, Artificial Intelligence (AI) technology has gotten intense attention in energy production and has immense prospective for the future design of energy systems. AI technology assists in making the energy industry more secure and efficient by evaluating and analyzing the data. The UAE is also diverted to the adoption of $\mathrm{AI}$ at the governmental level. It has opened new venues for the new generation towards digitalization. With AI technology, the UAE government intended to provide effective and efficient public services to the citizens. Digitalise public services have evolved over three stages of development where it has successfully implemented the e-government (electronic government) services then transformed to mobile government (smart/m-government) platform. Recently, the UAE government has 
shifted to artificial intelligence-enabled services. Hence, they established the Ministry of Artificial Intelligence. AI has become a core to any technological solutions that will be used for nearly all services and sectors, according to UAE AI vision and strategy for the next 15 years (Daleure, 2017).

According to UAE Minister of Artificial Intelligence, AI technology helps reshape the energy scene on a global scale. The contribution of $\mathrm{AI}$ to the UAE energy sector is reaching an estimated $\$ 2.85$ billion by 2020 (Antonopoulos et al., 2020). AI data analysis and the Internet of Things are rising as major elements in forecasting and estimating the energy sector. With oil prices fluctuation, the interruption of these novel technologies will attain high returns on security, safety, and efficiency, facilitating the country to make accurate and faster decisions (Bag et al., 2020). United Arab Emirates (UAE) is keen to exploit the benefits of AI in achieving its goals and aspiration for providing competent self-service technology government. UAE public sector has adopted AI technology in many of its services like in healthcare, security, business, and others; it is able to overcome the challenges in coordinating amongst ministries and agencies. Thus, it creates public trust with effective and efficient service delivery and avoids corruption (Cressey et al., 1998). Using AI-based services, government agencies improve the work efficiency and user experience, reduce service costs, and relieve human workloads (Buell, Campbell, \& Frei, 2010). Hence, the UAE government has promoted the adoption of $\mathrm{AI}$ in the energy; however, inspector. To adopt any technology in the field, it is essential to understand the factors affecting it. Hence, this study focused on prioritizing the factors human resource management factors affecting the adoption of $\mathrm{AI}$ in the energy sector of the UAE.

\section{LITERATURE REVIEW}

\subsection{Artificial Intelligence}

AI was formally coined around 1956 at a conference at the Dartmouth College, New Hampshire (McCarthy et al., 2017). Colloquially, artificial intelligence applies when a machine imitates the cognitive functions and aspects associated with human minds, for instance, problem-solving and learning. Artificial Intelligence (AI) focuses on creating intelligent devices and programs. It mimics human consciousness and also tries to perform any possible human tasks. This means the ability of a programmable machine to think and learn, which emulates human realization. AI adoption has become a vital portion of technology and processing industry advancement (Mao et al., 2019).

The invention of Artificial Intelligence (AI) encountered a lot of optimism as many experts argue it is the answer to some of the most complex challenges of human existence. However, artificial intelligence is an ever-changing phenomenon that only includes technological innovations that demonstrate the same cognitive abilities seen in humans. Artificial intelligence is still an ambiguous concept used on different technological innovations crucial to humankind (Poola, 2017).

Artificial Intelligence (AI) domains are categorized based on the expectation to change the world with AI technology such as in transportation; people interaction; service robots; healthcare; education; public safety/security, and others. In the transportation domain, the general public expects the reliability and safety of AI systems. Autonomous vehicles or transportation are the way forward with the help of AI technology. After the autonomous transportations are made satisfactorily safe and robust, the public can accept and adjust them voluntarily (Russell et al., 2015). AI dynamic approaches will utilize the limited resources in the transportation domain with data availability and extensive connectivity ( $\mathrm{Li}$ et al., 2018). Similarly, AI technology can model the communication and coordination between humans and machines by connecting humans and machines virtually (Kannan et al., 2019). Nowadays, the internet of things (IoT) and cloud systems devices are becoming more widespread in AI social and economic dimensions. Moreover, object recognition, robotics, and data-driven product platforms are proliferating (Russell et al., 2015; Kannan et al., 2019).

\subsection{Energy sector}

Energy is one of the most fundamental elements to drive economic development. It is involved in almost all the production and consumption of goods and services in modern society (Strydom et al., 2020). The energy sector involves a complex and inter-related network of companies or organizations in the production and distribution of energy to power the economy and facilitate production and transportation. The energy industry's performance helps to generate more revenue, reduce more costs, improve operational, explore activities, expand markets, and contribute to the national economy (Al-Damen 2017).

United Arab Emirates (UAE) energy depends considerably on oil \& gas resources and is recognized as significant petroleum producers 
around the world as cited by (Al Mansoori et. al. 2020). The energy sector is challenging, especially the market demand and supply of energy. UAE Government launched UAE Strategy for Artificial Intelligence (AI). Fluctuation and the dynamic of the current energy market make it challenging to meet all the energy demands. Hence, the UAE oil and gas sector is promoting the adoption of $\mathrm{AI}$ technology to make itself a global leader. AI can provide fast and intelligent automation as well as dynamic scalability to optimize the customers' purchase experience. Moreover, AI can accurately give computational facts and figures to offer clear and compelling evidence for the need for AI development and enhancement in the UAE energy sector (Nordrum, 2017).

\section{RESEARCH METHODOLOGY}

This paper focused on assessing the role of human resource management and technology factors on the adoption of AI technology in emery sector projects of the UAE. A strategic framework for carrying out this study is in figure 1 .

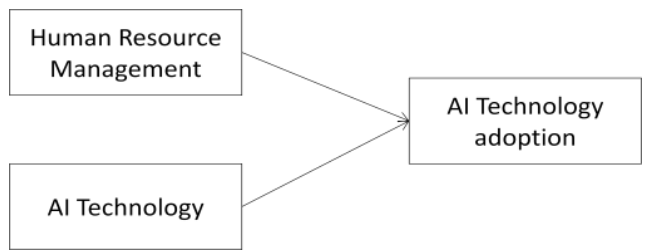

Figure 1. Research Framework

Figure 1 depicts that AI Technology is adoption is dependent on human resource management and AI technology. This study assessed the role of the independent variable with the help of various parameters from a comprehensive literature review. From the review of the published literature, a total of 11 parameters of human resource management and nine parameters of AI technology availability were identified. In contrast, AI technology adoption level was measured by investigating nine indicators identified from literature. The current study utilized a quantitative method of data collection as a quantitative approach of data analysis is most valued to the investigator for finding significant outcomes from vast data. A questionnaire form was used for data reading. The advantage of the questionnaire includes the potential time and cost savings, and the elimination of interview bias (Lewis, 2015).

This study used the Likert scale as the assessment scales to target the audience. When responding to Likert scale questions, respondents will determine their level of disagreement or agreement on asymmetric disagrees or agrees on scale for a sequence of statements (Lee \& Rha, 2016; Lewis,
2015). The Likert scale used for data collection was based $\mathrm{n}$ 5-points as 1 for strongly disagree, 2 for disagree, 3 for neutral, 4 for agree, and 5 for strongly agree. To analyze the data Statistical Package for Social Sciences (SPSS) was used. Researchers have largely used and accepted this software as a data analysis technique (Stevens, 2012).

Cronbach's alpha value of the data helped to determine the internal consistency of the data or the validity of the data (Amirrudin et al., 2020; Čaplová \& Švábová, 2020). Data were analyzed with the help of the RII technique to prioritize the parameters as adopted by (Akhund et al. 2019). Also, the normality of the data was assessed as the data must comply with the normality assumption. (Tabachnick \& Fidell, 2012) as abnormal data results in an error and can lead to making a wrong inference. Skewness and kurtosis methods are used to assess the normality of the data. (Pituch \& Stevens, 2016) stated that the rule of thumb for establishing normality using the skewness and kurtosis criterion is to compare the computed values with a magnitude of \pm 2 . Values that exceed this limit are considered to violate the normality assumption, while those that are less than 2 are considered to approximate a normal distribution.

\section{RESULTS AND DISCUSSION}

\subsection{Demography of the Respondents}

The survey was carried out through email, in person, LinkedIn, Facebook, Google form, and WhatsApp. As a result, 350 completed responses were received against 400 distributed forms, representing an $86.25 \%$ response rate, which is considered satisfactory (Pazzaglia et al., 2016). Before the data analysis, the respondents' demographic information was gathered, as summarized in table 1.

\begin{tabular}{|c|c|c|}
\hline Items & Frequency & Percentage \\
\hline \multicolumn{3}{|l|}{ Qualification } \\
\hline Bachelor degree & 175 & $50 \%$ \\
\hline Master's degree & 140 & $40 \%$ \\
\hline PhD degree & 35 & $10 \%$ \\
\hline \multicolumn{3}{|l|}{ Working Experience } \\
\hline Less than 5 years & 87 & $25 \%$ \\
\hline $6-10$ years & 175 & $50 \%$ \\
\hline $11-15$ years & 35 & $10 \%$ \\
\hline Above than 15 years & 53 & $15 \%$ \\
\hline \multicolumn{3}{|l|}{ Working Position } \\
\hline Executive & 175 & $50 \%$ \\
\hline $\begin{array}{l}\text { Senior executive/ } \\
\text { Head of Department }\end{array}$ & 140 & $40 \%$ \\
\hline Managers & 35 & $10 \%$ \\
\hline
\end{tabular}

Table 1. Respondent's demography 
Table 1 depicts that $50 \%$ of respondent participating in this data collection process have obtained engineering degrees while $40 \%$ of the respondents are master degree holders and $10 \%$ of respondents have completed their Ph.D. These respondents have been working in the field for several years and hold either management or executive posts in their respective firms. This shows that the respondent has a good level of understanding and is suitable for providing a factual position regarding the investigated objectives. Data collected from these respondents were tested for consistency with the help of a reliability test. The reliability test validated the internal consistency and quality of the research instruments (Souza et al., 2017, Daniel, 2010). Cronbach's alpha coefficient is widely used for testing reliability. Munir et al. (2019) suggested that the data is considered satisfactory if the Alpha value is more than 0.7 , as cited by (Islam et. al. 2020). In this study, Cronbach Alpha values for all the groups of the factors are shown in table 2 .

\begin{tabular}{|c|c|c|c|c|}
\hline 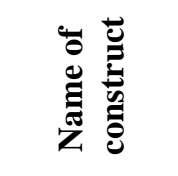 & 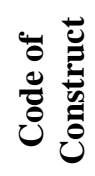 & 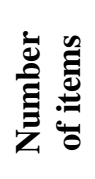 & 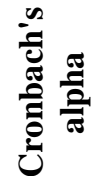 & 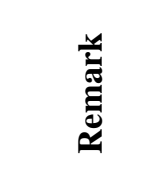 \\
\hline $\begin{array}{l}\text { AI } \\
\text { technology } \\
\text { adoption }\end{array}$ & AIE & 9 & 0.744 & Acceptable \\
\hline Technology & AIT & 9 & 0.881 & Good \\
\hline $\begin{array}{l}\text { Human } \\
\text { resources }\end{array}$ & HRM & 11 & 0.795 & Acceptable \\
\hline
\end{tabular}

Table 2. Reliability test of the survey data

Table 2 reveals that the Alpha value for all the three groups of parameters is above 0.7 . Hence, the data is considered reliable and suitable for further analysis. Based on the respondents' perception, RII value was calculated to prioritize the parameters as presented in table 3 .

\begin{tabular}{|c|c|c|c|c|c|c|c|c|c|}
\hline \multirow[b]{2}{*}{ Code } & \multirow[b]{2}{*}{ Attribute } & \multicolumn{5}{|c|}{ Scale/Frequency } & \multirow[b]{2}{*}{$\mathbf{N}$} & \multirow[b]{2}{*}{ RII } & \multirow[b]{2}{*}{ Rank } \\
\hline & & $\begin{array}{l}\text { strongly } \\
\text { disagree }\end{array}$ & disagree & neutral & agree & $\begin{array}{c}\text { strongly } \\
\text { agree }\end{array}$ & & & \\
\hline \multicolumn{10}{|c|}{ AI Technology adoption in UAE } \\
\hline AIE8 & $\begin{array}{l}\text { Organisation use } \\
\text { AI to provide } \\
\text { effective business } \\
\text { innovation }\end{array}$ & 17 & 39 & 111 & 110 & 73 & 350 & 0.705 & 1 \\
\hline AIE2 & $\begin{array}{l}\text { Organization use } \\
\text { AI to align with its } \\
\text { business strategy }\end{array}$ & 34 & 54 & 75 & 79 & 108 & 350 & 0.699 & 2 \\
\hline AIE9 & $\begin{array}{l}\text { Organisation use } \\
\text { AI to improve the } \\
\text { levels of } \\
\text { production }\end{array}$ & 17 & 68 & 80 & 131 & 54 & 350 & 0.678 & 3 \\
\hline AIE1 & $\begin{array}{l}\text { Organisation } \\
\text { authorised to } \\
\text { implement AI } \\
\text { Technology }\end{array}$ & 17 & 78 & 90 & 94 & 71 & 350 & 0.671 & 4 \\
\hline AIE5 & $\begin{array}{l}\text { Organisation use } \\
\text { AI for better } \\
\text { coordination }\end{array}$ & 18 & 78 & 87 & 108 & 59 & 350 & 0.664 & 5 \\
\hline AIE6 & $\begin{array}{l}\text { Organisation use } \\
\text { AI increase's } \\
\text { ability to anticipate } \\
\text { customers' demand }\end{array}$ & 16 & 89 & 78 & 122 & 45 & 350 & 0.652 & 6 \\
\hline AIE7 & $\begin{array}{l}\text { Organisation use } \\
\text { AI to assists in } \\
\text { predicting new } \\
\text { market segments }\end{array}$ & 42 & 54 & 105 & 94 & 55 & 350 & 0.638 & 7 \\
\hline AIE3 & $\begin{array}{l}\text { Organisation adopt } \\
\mathrm{AI} \text { in decision } \\
\text { making }\end{array}$ & 35 & 93 & 76 & 92 & 54 & 350 & 0.621 & 8 \\
\hline AIE4 & $\begin{array}{l}\text { Organisation use } \\
\text { AI to improve } \\
\text { communication }\end{array}$ & 62 & 85 & 63 & 105 & 35 & 350 & 0.581 & 9 \\
\hline
\end{tabular}




\begin{tabular}{|c|c|c|c|c|c|c|c|c|c|}
\hline \multicolumn{10}{|c|}{ AI Technology [AIT] } \\
\hline AIT7 & $\begin{array}{l}\text { AI Technology is } \\
\text { user friendly }\end{array}$ & 16 & 45 & 86 & 102 & 101 & 350 & 0.730 & 1 \\
\hline AIT3 & $\begin{array}{l}\text { AI Technology is } \\
\text { able to improve the } \\
\text { quality of the work }\end{array}$ & 12 & 36 & 104 & 121 & 77 & 350 & 0.723 & 2 \\
\hline AIT8 & $\begin{array}{l}\text { AI Technology fits } \\
\text { well with the tasks } \\
\text { involved }\end{array}$ & 22 & 68 & 61 & 91 & 108 & 350 & 0.711 & 3 \\
\hline AIT9 & $\begin{array}{l}\text { AI Technology is } \\
\text { compatible with } \\
\text { other systems }\end{array}$ & 28 & 48 & 83 & 95 & 96 & 350 & 0.705 & 4 \\
\hline AIT1 & $\begin{array}{l}\text { AI Technology is } \\
\text { useful for the given } \\
\text { job }\end{array}$ & 14 & 41 & 128 & 88 & 79 & 350 & 0.701 & 5 \\
\hline AIT4 & $\begin{array}{l}\text { AI Technology } \\
\text { makes easier to } \\
\text { carry out the tasks }\end{array}$ & 15 & 66 & 90 & 99 & 80 & 350 & 0.693 & 6 \\
\hline AIT6 & $\begin{array}{l}\text { AI Technology } \\
\text { makes data analysis } \\
\text { easier }\end{array}$ & 26 & 51 & 98 & 97 & 78 & 350 & 0.686 & 7 \\
\hline AIT5 & $\begin{array}{l}\text { AI Technology } \\
\text { provides accurate } \\
\text { information }\end{array}$ & 25 & 57 & 109 & 102 & 57 & 350 & 0.662 & 8 \\
\hline AIT2 & $\begin{array}{l}\text { AI Technology } \\
\text { able to perform the } \\
\text { tasks faster }\end{array}$ & 26 & 72 & 98 & 96 & 58 & 350 & 0.650 & 9 \\
\hline \multicolumn{10}{|c|}{ Human resources management [HRM] } \\
\hline HRM6 & $\begin{array}{l}\text { Employee need } \\
\text { training of using AI } \\
\text { Technology }\end{array}$ & 12 & 59 & 76 & 81 & 122 & 350 & 0.738 & 1 \\
\hline HRM7 & $\begin{array}{l}\text { Referral person is } \\
\text { required if facing } \\
\text { difficulty with AI } \\
\text { Technology }\end{array}$ & 7 & 67 & 67 & 120 & 89 & 350 & 0.724 & 2 \\
\hline HRM2 & $\begin{array}{l}\text { Teammate support } \\
\text { in using AI } \\
\text { Technology }\end{array}$ & 12 & 64 & 89 & 101 & 84 & 350 & 0.703 & 3 \\
\hline HRM8 & $\begin{array}{l}\text { Employees should } \\
\text { be given feedback } \\
\text { about using AI } \\
\text { Technology }\end{array}$ & 6 & 73 & 76 & 126 & 69 & 350 & 0.702 & 4 \\
\hline HRM3 & $\begin{array}{l}\text { Enough resources } \\
\text { to work using AI } \\
\text { Technology }\end{array}$ & 13 & 61 & 92 & 123 & 61 & 350 & 0.690 & 5 \\
\hline HRM9 & $\begin{array}{l}\text { Employees need } \\
\text { time to implement } \\
\text { AI Technology }\end{array}$ & 20 & 62 & 90 & 112 & 66 & 350 & 0.681 & 6 \\
\hline HRM5 & $\begin{array}{l}\text { Employee require } \\
\text { specific knowledge } \\
\text { of AI Technology }\end{array}$ & 22 & 74 & 84 & 94 & 76 & 350 & 0.673 & 7 \\
\hline HRM1 & $\begin{array}{l}\text { Management insists } \\
\text { on using AI } \\
\text { Technology }\end{array}$ & 15 & 80 & 99 & 92 & 64 & 350 & 0.663 & 8 \\
\hline $\begin{array}{c}\text { HRM1 } \\
1\end{array}$ & $\begin{array}{l}\text { Employees are } \\
\text { willing to learn to } \\
\text { use AI Technology }\end{array}$ & 28 & 70 & 90 & 96 & 66 & 350 & 0.658 & 9 \\
\hline
\end{tabular}




\begin{tabular}{|c|c|c|c|c|c|c|c|c|c|}
\hline HRM4 & $\begin{array}{l}\text { Organization insists } \\
\text { using AI } \\
\text { Technology }\end{array}$ & 29 & 53 & 117 & 90 & 61 & 350 & 0.658 & 9 \\
\hline $\begin{array}{c}\text { HRM1 } \\
0\end{array}$ & $\begin{array}{l}\text { Organisation } \\
\text { should make } \\
\text { preparation to use } \\
\text { AI Technology in } \\
\text { future }\end{array}$ & 13 & 83 & 116 & 81 & 57 & 350 & 0.649 & 10 \\
\hline
\end{tabular}

Table 3. Respondent's demography

Table 3 shows that top three parameters in AI adoption category are "organisation use AI to provide effective business innovation", "organization use AI to align with its business strategy", and "organisation use AI to improve the levels of production". From technological availability, the top three of 9 investigate parameters are AI Technology is user friendly, AI Technology is able to improve the quality of the work and AI Technology fits well with the tasks involved. Similarly, we examined the parameters of human resource management for adoption of AI in energy section. Based on RII value top 3 parameters are employee need training of using AI technology, referral person is required if facing difficulty with AI technology and teammate support in using AI technology. Normality of the data was assessed by skewness and kurtosis of the data. It was calculated for all the groups of the parameters as in table 4.

\begin{tabular}{|c|c|c|c|c|}
\hline & \multicolumn{2}{|c|}{ Skewness } & \multicolumn{2}{|c|}{ Kurtosis } \\
\hline & 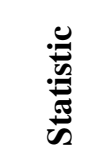 & $\begin{array}{l}\ddot{0} \\
\stackrel{0}{0} \\
\dot{0} \\
\dot{0}\end{array}$ & & 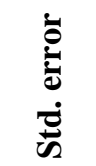 \\
\hline AIE & -0.342 & 0.130 & -0.724 & 0.260 \\
\hline AIT & -0.239 & 0.130 & -0.871 & 0.260 \\
\hline HRM & -0.277 & 0.130 & -0.805 & 0.260 \\
\hline
\end{tabular}

Table 4. Results of normality test

Table 4 reveals that all the groups of the parameters have skewness and kuttosis value in the range of \pm 2 . It means that the data fulfills the normality assumption and is considered suitable to draw a conclusion.

\section{CONCLUSION}

Artificial intelligence (AI) technologies have shown increasing growth in various industry sectors such as education, healthcare, the environment, and others. AI-based technologies facilitate making decisions based on interactions with the environment. Thus, it is imperative to understand the factors affecting/influencing the AI technology adoption from the user's perspective. Hence, this study assessed the parameters affecting AI adoption in the UAE energy sector. A total of 350 data samples were collected and analyzed statistically. From data analysis, it was realized that;

$>$ The top three parameters are "Organization use AI to provide effective business innovation", "Organizations use AI to align with its business strategy", and "Organization use AI to improve the levels of production".

$>$ Significant parameters of AI technology include are; AI Technology is user friendly, AI Technology is able to improve the quality of the work and AI Technology fits well with the tasks involved.

$>$ Referral person is required if facing difficulty with AI technology and teammate support in using AI technology are essential parameters of the human resource management which affect AI adoption in energy sector of the UAE.

Reliability test validated the quality and internal consistency of the data. Normality of the data was assessed by skewness and kurtosis of the data. The findings of this study can be utilized as a visual tool to understand the factors affecting the adoption of Artificial Intelligence (AI) in the UAE energy sector by the energy players and the readiness to embrace artificial intelligence in the energy industry, which faces many challenges now ahead.

\section{REFERENCES}

Akhund, M. A., Memon, A. H., Ali, T. H., Memon, N. A., \& Kazi, S. (2019). Waste management in construction projects of pakistan. Pakistan Journal of Science, 71(4), 59.

Al-Damen, R. A. (2017). The Impact of Total Quality Management on organizational performance Case of Jordan Oil Petroleum Company. International Journal of Business and Social Science, 8(1), 192-202

Al Mansoori, F. T., Rahman I. A. \& Kasim, R. 
(2020). Deciding the Rank of Factors Affecting Abu Dhabi Oil \& Gas Industry. International Journal of Sustainable Construction Engineering and Technology, 11(2), 133-139

Amirrudin, M., Nasution, K., \& Supahar, S. (2020). Effect of Variability on Cronbach Alpha Reliability in Research Practice. Jurnal Matematika, Statistika Dan Komputasi, 17(2), 223-230. https://doi.org/10.20956/jmsk.v17i2.11655

Antonopoulos, I., Robu, V., Couraud, B., Kirli, D., Norbu, S., Kiprakis, A., Flynn, D., ElizondoGonzalez, S., \& Wattam, S. (2020). Artificial intelligence and machine learning approaches to energy demand-side response: A systematic review. In Renewable and Sustainable Energy Reviews. https://doi.org/10.1016/j.rser.2020.109899

Bag, S., Pretorius, J. H. C., Gupta, S., \& Dwivedi, Y. K. (2020). Role of institutional pressures and resources in the adoption of big data analytics powered artificial intelligence, sustainable manufacturing practices and circular economy capabilities. Technological Forecasting and Social Change.

https://doi.org/10.1016/j.techfore.2020.120420

Brynjolfsson, E., \& Mitchell, T. (2017). What can machine learning do? Workforce implications: Profound change is coming, but roles for humans remain. Science, 358(6370), 1530-1534. https://doi.org/10.1126/science.aap8062

Buell, R. W., Campbell, D., \& Frei, F. X. (2010). Are self-service customers satisfied or stuck? Production and Operations Management, 19(6), 679-697. https://doi.org/10.1111/j.19375956.2010.01151.x.

Čaplová, Z., \& Švábová, P. (2020). IBM SPSS statistics. In Statistics and Probability in Forensic Anthropology, 343-352, https://doi.org/10.1016/b978-0-12-8157640.00027-7

Cressey, P., Grint, K., \& Woolgar, S. (1998). The Machine at Work: Technology, Work and Organisation. The British Journal of Sociology. https://doi.org/10.2307/591331

Daleure, G. (2017). Economic Vision of the UAE. In Emiratization in the UAE Labor Market, pp. 2737, Springer Singapore. https://doi.org/10.1007/978-981-10-2765-9_3

Daniel, M. (2010). Introduction to quantitative research 1.1. Doing Quantitative Research in Education with SPSS.
Frey, C. B., \& Osborne, M. A. (2017). The future of employment: How susceptible are jobs to computerisation? Technological Forecasting and Social Change, 114, 254-280. https://doi.org/10.1016/j.techfore.2016.08.019

Soomro, N. U. I., Memon, A. H., Memon, N. A. \& K. R. Memon. (2020). Contractor's Selection Criteria in Construction Works in Pakistan. Engineering, Technology \& Applied Science Research, 10(2), 5520-5523. https://doi.org/10.48084/etasr.3334

Kannan, K. N., Pamuru, V., \& Rosokha, Y. (2019). Using Machine Learning for Modeling Human Behavior and Analyzing Friction in Generalized Second Price Auctions. SSRN Electronic Journal. https://doi.org/10.2139/ssrn.3315772

Lee, J. M., \& Rha, J. Y. (2016). Personalizationprivacy paradox and consumer conflict with the use of location-based mobile commerce. Computers in Human Behavior. https://doi.org/10.1016/j.chb.2016.05.056

Lewis, S. (2015). Qualitative Inquiry and Research Design: Choosing Among Five Approaches. In Health Promotion Practice. https://doi.org/10.1177/1524839915580941

Li, C., Xie, C., Zhang, B., Chen, C., \& Han, J. (2018). Deep Fisher discriminant learning for mobile hand gesture recognition. Pattern Recognition, 77, 276-288. https://doi.org/10.1016/j.patcog.2017.12.023

Mao, S., Wang, B., Tang, Y., \& Qian, F. (2019). Opportunities and Challenges of Artificial Intelligence for Green Manufacturing in the Process Industry. In Engineering. https://doi.org/10.1016/j.eng.2019.08.013

McCarthy, S. M., Vayanos, P., \& Tambe, M. (2017). Staying ahead of the game: Adaptive robust optimization for dynamic allocation of threat screening resources. IJCAI International Joint Conference on Artificial Intelligence, 0, 37703776. https://doi.org/10.24963/ijcai.2017/527

Munir, M. A., Zaheer, M. A., Haider, M., Rafique, M. Z., Rasool, M. A. \& Amjad, M. S. (2019). Problems and barriers affecting total productive maintenance implementation. Engineering, Technology \& Applied Science Research, 9(5), 4818-4823

Nordrum, A. (2017). Govern by blockchain dubai wants one platform to rule them all, while Illinois will try anything. IEEE Spectrum. https://doi.org/10.1109/MSPEC.2017.8048841 
Pazzaglia, A. M., Stafford, E. T., \& Rodriguez, S. M. (2016). Survey methods for educators: Analysis and reporting of survey data (part 3 of 3 ). In Applied Resarch Methods.

Pirani, S. I., \& Arafat, H. A. (2016). Reduction of food waste generation in the hospitality industry. Journal of Cleaner Production, 132, 129-145. https://doi.org/10.1016/j.jclepro.2015.07.146

Pituch, K. A., \& Stevens, J. P. (2016). Applied multivariate statistics for the social sciences: Analyses with SAS and IBM's SPSS. In Routledge.

Poola, I. (2017). How Artificial Intelligence in Impacting Real Life Every day. International Journal of Advance Research and Development.

Russel, S., \& Norvig, P. (2012). Artificial intelligence - a modern approach 3rd Edition. In The Knowledge Engineering Review. https://doi.org/10.1017/S0269888900007724

Russell, S., Dewey, D., \& Tegmark, M. (2015). Research priorities for robust and beneficial artificial intelligence. AI Magazine, 36(4), 105114. https://doi.org/10.1609/aimag.v36i4.2577

Strydom, A., Musango, J. K., Currie, P. K. (2020). Connecting energy services, carriers and flows: rethinking household energy metabolism in Cape Town, South Africa, Energy Res. Social Sci., 60, Article 101313

Stevens, J. P. (2012). Applied Multivariate Statistics for the Social Sciences. In Applied Multivariate Statistics for the Social Sciences. Routledge. https://doi.org/10.4324/9780203843130

Souza, D. C., Wegner, F., Costa, L. C. M., Chiavegato, L. D., \& Lunardi, A. C. (2017). Measurement properties of the Human Activity Profile questionnaire in hospitalized patients. Brazilian Journal of Physical Therapy. https://doi.org/10.1016/j.bjpt.2017.03.011

Tabachnick, B. G., \& Fidell, L. S. (2012). Using multivariate statistics (6th ed.). In New York: Harper and Row. 